\title{
Effects of Relationship Quality on Citizen Intention Use of E- government Services: An Empirical Study of E-government System
}

\author{
Berlilana $^{1}$, Taqwa Hariguna ${ }^{2}$, Min Tsai Lai ${ }^{3}$ \\ ${ }^{1,2}$ Department of Information System, STMIK Amikom Purwokerto, Indonesia \\ ${ }^{3}$ Department of Business Administration, Southern Taiwan University of Science and Technology, Taiwan
}

\begin{tabular}{|c|c|}
\hline Article Info & ABSTRACT \\
\hline Article history: & This study aims to explain the concept of relationship quality on citizen \\
\hline Received Mar 23, 2018 & $\begin{array}{l}\text { intention use of e-Government service. We have built } 5 \text { hypotheses. The } \\
\text { result of } 5 \text { hypotheses is positive and significant impact. In building citizen }\end{array}$ \\
\hline Revised Jul 20, 2018 & relationship, we build two antecedent they are perceived e-Government \\
\hline Accepted Aug 4, 2018 & $\begin{array}{l}\text { usability and perceived e-Government credibility. The method we use in this } \\
\text { research is empirical, with } 366 \text { valid respondents. }\end{array}$ \\
\hline
\end{tabular}

Keyword:

Citizen relationship

E-government

Perceived credibility

Perceived usability

\section{Corresponding Author:}

Taqwa Hariguna,

Department of Information System,

STMIK Amikom Purwokerto,

Jl. Pol Sumarto, Watumas, Purwokerto, Jawa Tengah, Indonesia.

Email: taqwa@amikompurwokerto.ac.id

\section{INTRODUCTION}

In general, electronic government (e-Government) can be defined as a medium that can connect the interaction between citizen, business actors or government with government by utilizing information and communication technology [1]. E-Government exists because the problems in society today are increasingly complex and require fast and precise handling [1], [2]. The existence of e-Government provides many benefits to civil society, but only few got its worthiness. The problems faced are very varied such as thecontent is not interesting, the system is not functioning properly and lack ofthe information [3].

Generally, the study of e-government is divided into tree classifications they are, first is the evolution of the e-government which includes the process of development, second the implementation of egovernment and third the impact or adoption of e-government use [4], [5]. Some previous studies confirmed that e-government development has increased significantly in some countries. It is because the impact of egovernment implementation can provide benefits to improve service quality, to grow democracy, to reduce corruption, to increase transparency, to reduce social gap, to improve competitive business, and to improve the quality of services in the community environment [6], [7].

Service is an intangible activity but has significant consequences, although in a service process there are many complicated procedures. Basically, marketing relationship quality is the root of a relationship between the vendor and the customer [6]. Some of literatures about traditional business marketing generally focus on two things, namely customer satisfaction and trust in the vendor, both of which are used as a key dimension in relationship quality. This confirms that a good relationship between customers and vendors is 
necessary. Satisfaction reflects the circumstances resulting from customer evaluation of past performance by vendors, while trust reflects buyers' trust in performance by vendors. Thus, customer and vendor relationships can be valued well if vendors in the past and future will benefit. This confirms that the quality of relationships resulting from trust and satisfaction play an important role in increasing loyalty.

In the context of e-government relations between communities and governments can be represented by using information systems, such as licensing, auctions, tax payments and information distribution. The two elements of relationship quality become part of the benchmark in the application of e-government. Trust and satisfaction are used by the community as a benchmark to ensure and evaluate the performance of egovernment services.

Thus, relationship quality has been recognized by previous researchers as an element that can serve as a benchmark for the success of a relationship to achieve e-government intention use [2], [4], [6]. In this study we use trust and satisfaction as a construct to measure relationship quality in e-government.In addition, in this study we used two antecedents that have correlation to relationship quality and citizen intention usei.e perceived e-government usability and perceived government credibility.In this study we focus on egovernment relationship quality, and examine the impact of relationship quality on citizen intention use of egovernment service, but it also examines some key relationship quality antecedents consisting of credibility and usability.

\section{LITERATURE REVIEW DAN HIPOTESIS}

\subsection{Perceived E-government Usability}

Perceived e-government usability can be defined as follows: (a) ease of understanding the structure of e-government by the community, (b) the level of ease in using e-government, (c) the speed in accessing data and information on e-government, (d) the use of easy-to-use navigation so as to generate conclusions according to user needs, (e) conformity control over what is being done, wherever and at any time [2] [4] [6]. Usability is key factors for web applications. In addition usability makes the information system can be more easy to use. The main concept is to adjust to the needs of users. [3] Defined usability as the ability of a software product so that the website can be understood, studied, operated, and appealing to users [3].

In software engineering study, usability is used to be a path of a system in order to make the system clear and easy to use. The main concept is to adjust the needs of users. In another study, [3] described usability as a capability of software which is understandable and well operated [3]. More about software engineering study, [8], [9] confirmed usability as one of the methods to verify the software development and software implementation [7], [10]. In term of computer behavior, usability is used to assess user loyalty of the website [11]. Crosby et al. confirmed that usability can affect the ease of e-government use and will ultimately affect the continued use of services in e-government [12].

Fernandez et al., Kim and Eom concluded that usability was an important factor in achieving user satisfaction [8], [13]. Fernandez et al., Maditinos and Theodoridis showed that the quality of the interface and the quality of information provided to consumers (two key aspects of web site usability) had a significant effect on the level of user satisfaction [9], [14]. According to all these ideas, we propose the following hypothesis: H1. Perceived e-government usability has a positive influence on e-government relationship quality. $\mathrm{H} 2$. Perceived e-government usability has a positive influence on citizen intention use of e-government.

\subsection{Perceived E-government Credibility}

The fundamental provision of credibility is the quality and reliance. In the area of human computer behavior, credibility is utilizedto elucidate the activity between systems and information [15]. Defined credibility as the trust of information on the website [16]. In the last, credibility was the piece of plausibility [17]. Figured credibility as an important factor and had relevance to perceptual manner to establish affective idea for consumers [18]. In the line of computer graphics, credibility is utilize for an activity that is used to test the perception effect on the application display of the users of the junction [13]. Other studies described the important role of credibility in shaping perceptions for students who used scientific websites with regard to the information they got [14], [19]. Asserted that credibility and trust, an important part of digging information online, was used as a cognitive heuristic proof [15].

Hariguna et al. Explained there was a positive relationship of existing features and perceptions of credibility on a web application [2]. Aesthetics and credibility in website design was essential to ensure sales, or to provide good service [16]. In terms of web application dispatch, credibility was the tight of relationship to dynamism that includedunpredict factors such as design and aesthetics [17]. Several research has utilized several standards to delineate credibility, which enables a more broad perceptivity [20]. Compressed the criteria of credibility, and elucidate it as reliability, confidence, competency, precision, and quality [21]. In the term of e-government, confirm that a website is believable was a decent and fundamental [3]. However, 
the argument citizens did not belief e-government services was because of the insufficiency of warranty in online activity for storing private information, although cyber regulations [1]. Therefore, e-government providers need to reflect credibility because of the perceived credibility on e-government services, can affect trust and satisfaction.

In another study, [22] Affirmed that the credibility of the website and user behavior had a strong relationship [23]. The source of credibility had also been validated to have a significant impact on trust and satisfaction [24]. Described a credible website generated favorable reactions from users [19]. Therefore we conclude:

H3. Perceived e-government credibility has a positive influence on e-government relationship quality.

H4. Perceived e-government credibility has a positive influence on perceived e-government usability.

\subsection{E-government Relationship Quality}

Relationship quality can be interpreted as an interaction that has been done by two different parties and have an impact on the activity. So the result must meet the expectations of both parties. Therefore, the result of the interaction between the two must meet the expectations of both parties. So the results can be evaluated based on success or a failure. In the view of [12] if the relationship quality of the firm with the customer had a good bond, it would have an impact on the customer, where the customer himself thought that satisfaction was part of the interaction with the company, but it also affected the effectiveness of the sales force in terms of giving long term service [6].

A number of studies have suggested that relationship quality had important indicators of trust, satisfaction, and commitment as a benchmark for the relationship quality, while trust and satisfaction remained key indicators. Although these theories did not conclude specifically that relationship quality exerts a strong influence on intent in the field of e-Government use, other studies also provided explicit explanations that relationship quality affected the intention of information technology. Scientists agreed that the chain of belief-satisfaction-behavior had causality that can ultimately improve behavior for the user, and satisfaction was one of the influences that can be an indicator.

Satisfaction and trust were two indicators that have been widely used by researchers to confirm the effect on the influence of one's intentions especially in information technology such as technological acceptance model (TAM), IS success model of Delone and McLean and the study of expectation confirmation model (ECM). Previous findings suggested a substantial relationship between satisfaction and user intention use. Meanwhile, some other scholars confirmed that citizen satisfaction has ability to increase citizen intention in the field of technology adoption [25]. Concluded that user satisfaction positively has relationship with user intention.

In the field of e-government [26], [27], [2] indicated that user satisfaction was an important factor for the continued use of e-government services, and for e-government success or failure [2], [4].

H5. E-Government relationship quality has a positive influence on citizen intention use of e-government

\section{RESEARCH DESIGN}

This research utilizes quantitative method. Data collect by questionnaire and utilize references from previous study [2], [20]. In this study, utilized five likert scale: strongly disagree (1) disagree (2) neutral (3) agree (4) and strongly agree (5), the questionnaire utilize was divided into three group: demographic, characteristics of information and number of data. Table 1 figure out the demographics of the respondents and Figure 1 elucidate the hypothesis framework.

Table 1. Demographics of the sample

\begin{tabular}{lll}
\hline Characteristics & Frequency & Percent $(\%)$ \\
\hline Gender & & \\
$\quad$ Male & 156 & 42.6 \\
$\quad$ Female & 210 & 57.4 \\
Age & & \\
$\quad$ 21-30 years old & 82 & 22.4 \\
31-40 years old & 170 & 46.4 \\
$\quad$ 41 years old or above & 114 & 31.1 \\
Education level & & \\
$\quad$ High school certificate or lower degree & 66 & 18.0 \\
$\quad$ Undergraduate degree & 180 & 49.2 \\
$\quad$ Master or higher degree & 120 & 32.8 \\
Experiences & & \\
$\quad$ Less than 3 times/year & 75 & 20.5 \\
$\quad$ 3-5 time/year & 121 & 33.1 \\
$\quad$ More than 5 time/years & 170 & 46.4 \\
\hline
\end{tabular}




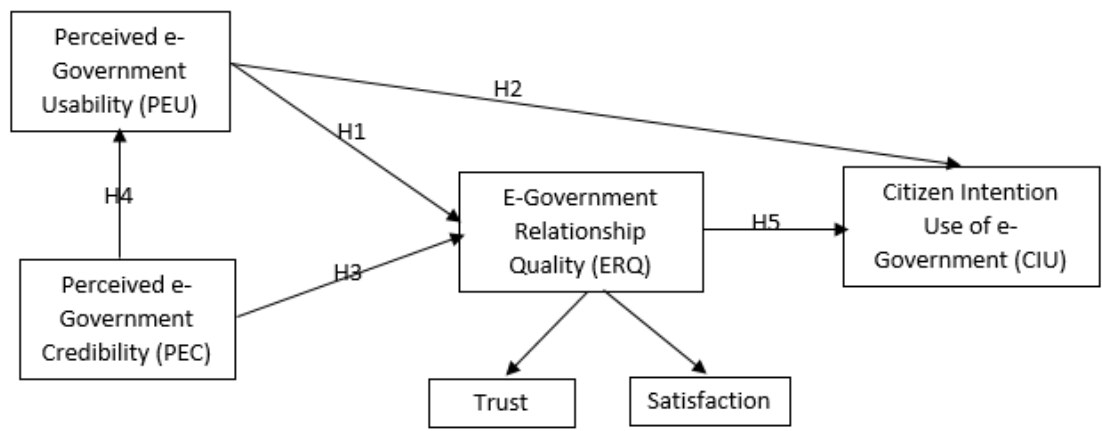

Figure 1. Research framework

\section{RESULTS OF THE DATA ANALYSIS}

In this study, we added relationship quality as mediation to citizen intention use of e-government service, and we integrated credibility and usability as antecedent rather than relationship quality and citizen intention use. Through this concept, this study has high value and high originality from the previous study. Most of the scholars described and used TAM, ECM and IS success models in order to measure egovernment performance success, but until now none of the studies focus on the relationship quality as the antecedent of citizen intention use of e-government.

In this research, we utilize software of SmartPLS to elaborate, to examine data and hypotheses. The technique utilizes in PLS was structural equation modeling. PLS was utilized to elaborate the model with two process indicators simultaneously they are reflective and formative. Moreover, PLS can be utilized to analyze data with large or small number, elaborate model of complex predictions, and help multicollinearity problems. Outer model was used to measure the relationship between indicators and latent construction on PLS. In addition, an inner model was utilized to assess the path structures between constructs [22] [24] [25].

\subsection{Outer Models}

Two tests required in outer models: items construct and construct validity [28]. Justify that the items construct utilize cronbach $\alpha$ and composite reliability as an indicator, where the number must be higher than 0.7 , then the construction achieved accepted and reliable [27]. Meanwhile, to measure construct validity utilize with two ways, convergent validity test, and discriminant validity test. Based on [28], it was confirmed a construction can be achieved convergent validity if the loading factor of each indicator higher than 0.5 [27]. In addition, the number of the average variance extracted (AVE) must be higher than 0.5 and the number of the composite reliability must be higher than 0.7 . Table 2 illustrates factor loads, reliability tests and all constructions are appropriate with [28].

In addition from Table 3 it shows that the square root of AVE was greater than the correlation coefficient of the constructs was tested to confirm discriminant validity. According to Table 2 and Table 3 , the constructs exhibited discriminant validity.

Table 2. Reliability analysis and convergent validity

\begin{tabular}{|c|c|c|c|c|c|}
\hline Construct & $\begin{array}{c}\text { Measurement } \\
\text { items }\end{array}$ & $\begin{array}{c}\text { Factor loading/coefficient } \\
\text { (t-value) }\end{array}$ & $\begin{array}{l}\text { Composite } \\
\text { reliability }\end{array}$ & AVE & Cronbach's $\alpha$ \\
\hline Perceived e- & PEU1 & 0.65 & & & \\
\hline Government & PEU2 & 0.85 & & & \\
\hline Usability (PEU) & PEU3 & 0.87 & 0.84 & 0.64 & 0.70 \\
\hline Perceived e- & PEC1 & 0.77 & & & \\
\hline Government & PEC2 & 0.88 & & & \\
\hline Credibility (PEC) & PEC3 & 0.87 & 0.88 & 0.70 & 0.80 \\
\hline & TRU1 & 0.86 & & & \\
\hline $\begin{array}{l}\text { e-Government } \\
\text { Relationshin }\end{array}$ & TRU2 & 0.73 & & & \\
\hline \multirow{4}{*}{ Quality (ERQ) } & TRU3 & 0.84 & & & \\
\hline & SAT1 & 0.61 & & & \\
\hline & SAT2 & 0.83 & 0.87 & 0.53 & 0.81 \\
\hline & SAT3 & 0.71 & & & \\
\hline Citizen Intention & CIU1 & 0.78 & & & \\
\hline Use of e- & CIU2 & 0.93 & & & \\
\hline Government (CIU) & CIU3 & 0.78 & 0.87 & 0.69 & 0.78 \\
\hline
\end{tabular}

Int J Elec \& Comp Eng, Vol. 8, No. 6, December 2018 : 5127 - 5133 
Table 3. Correlation matrix

\begin{tabular}{lllll}
\hline & CIU & ERQ & PEC & PEU \\
\hline CIU & 0.83 & & & \\
ERQ & 0.53 & 0.73 & & \\
PEC & 0.52 & 0.72 & 0.84 & \\
PEU & 0.72 & 0.62 & 0.60 & 0.80 \\
\hline
\end{tabular}

Note: Perceived e-Government Usability (PEU); Perceived e-Government Credibility (PEC);

e-Government Relationship Quality (ERQ); Citizen Intention Use of e-Government (CIU).

\subsection{Inner Model}

In the PLS to measure the significance of the benchmark hypothesis used is the path coefficient Tvalues, in Table 4 describes the results of the hypotheses of all significant and positive values.

Table 4. Summary of hypotheses testing results

\begin{tabular}{lllll}
\hline Hypothesis & Path & $\begin{array}{l}\text { Standardized } \\
\text { path coefficient }\end{array}$ & T-value & Supported \\
\hline H1 & PEU-ERQ & $0.57 * * *$ & 8.16 & Yes \\
H2 & PEU-CIU & $0.98 * * *$ & 19.06 & Yes \\
H3 & PEC-ERQ & $0.40 * * *$ & 6.25 & Yes \\
H4 & PEC-PEU & $0.59 * *$ & 10.32 & Yes \\
H5 & ERQ-CIU & $0.43 * * *$ & 5.78 & Yes
\end{tabular}

Note 1: Perceived e-Government Usability (PEU); Perceived e-Government Credibility (PEC);

e-Government Relationship Quality (ERQ); Citizen Intention Use of e-Government (CIU).

Note 2: **p-value $<0.01 ; * * *$ p-value $<0.001$

\subsection{Testing of Mediation Effects}

In this study there are three mediation effects that must be tested, to test the significance of all three used Sobel test to analyze, which to get a significant value then z-value must be worth 1.96 or more [29] [30]. In this study we found that the three have met the criteria and significant value, as shown in Table 5.

Table 5. Mediation effects testing

\begin{tabular}{llll}
\hline Constructs & Construct relationships & T-value of path coefficients & Sobeltest's z-value \\
\hline \multirow{2}{*}{ PEU-ERQ-CIU } & PEU-ERQ & 8.16 & $4.71 * * *$ \\
& ERQ-CIU & 5.78 & \\
\multirow{2}{*}{ PEC-ERQ-CIU } & PEC-ERQ & 6.25 & $4.24 * * *$ \\
& ERQ-CIU & 5.78 &
\end{tabular}

Note 1: Perceived e-Government Usability (PEU); Perceived e-Government Credibility (PEC); e-Government

Relationship Quality (ERQ); Citizen Intention Use of e-Government (CIU).

Note 2: ***p-value $<0.001$

\section{DISCUSSION}

This study aims to measure the performance results of e-government implementation based on user perspective. In this research the approach used is empirical relationship quality as a mediator in assessing the performance of e-government to determine citizen intention use. Assessment used multi-dimensional factor, refered to research that has been done by previous researchers [2] [4] [6].

This study provides explicit impacts for the academic world and practitioners in the field of egovernment. Based on the analysis results found that $\mathrm{H} 1$ and $\mathrm{H} 5$ have significant direct impact on CIU, while $\mathrm{H} 1$ and $\mathrm{H} 3$ are significant to CIU indirectly. In addition, $\mathrm{H} 4$ is significant to PEU, and also significant to CIU indirectly. Meanwhile PEU and PEC are the two main variable factors that support ERQ as confirmed by [28] [2].

\section{CONCLUSION}

The contribution of this research applies the concepts of PEU and PEC to add relationship quality as an intermediary variable to build a comprehensive framework for analyzing the impact on the continuing intentions for e-government. In the procurement concept the customer or user will always repeat the purchasing behavior, buy another product from the same company, and will set aside the influence of the 
competitor. Thus, relationship quality can be a successful instrument or marketing mechanism including the use of e-government. The influence of citizen credibility and high citizen usability has an effect on high relationship quality which also has a positive impact on loyalty and continuity of intention. The context of cause and effect can be a reference for the development of managerial strategies for e-government organizers. Most research focuses on the quality of e-government only. This study applies PEU, PEC and extends it to include relationship quality as an intermediary variable to develop a comprehensive framework in order to analyze the impact and impact on continued intentions of e-government use.

\section{REFERENCES}

[1] Bélanger F., \& Carter L., "Trust and risk in e-government adoption”, The Journal of Strategic Information Systems, 17(2), 165-176, 2008

[2] Hariguna T., Lai MT., \& Chen SC., "Understanding information system quality on public e-government service intention: an empirical study", Int. J. Innovation and Sustainable Development, 11(2/3), 271-290, 2017.

[3] Huang Z., \& Benyoucef M., "Usability and credibility of e-government websites", Government Information Quarterly, 31(4), 584-595, 2014.

[4] Jalaldeen M., Razi M., Izzuddin M., Tamrin M., Rahman A., \& Dahlan A., “Antecedents of Knowledge Management Practices: Case of Malaysian Practitioners", Bulletin of Electrical Engineering and Informatics, 7(1), 125-133, 2018.

[5] Rghioui A., \& Oumnad A., "Internet of things: Surveys for measuring human activities from everywhere", International Journal of Electrical and Computer Engineering, 7(5), 2474-2482. 2017.

[6] Ajayi B., \& Hussin H., "Conceptualizing Information Technology Governance Model for Higher Education: An AbsorptiveCapacity Approach", Bulletin of Electrical Engineering and Informatics, 7(1), 117-124, 2018.

[7] Achmad K.A., Nugroho L.E., Djunaedi A., \& Widyawan, "Smart city readiness based on smart city council's readiness framework", International Journal of Electrical and Computer Engineering, 8(1), 271-279, 2018.

[8] Fernandez A., \& Insfran E., \& Abrahão S., "Usability evaluation methods for the web: A systematic mapping study", Information and Software Technology, 53(8), 789-817, 2011.

[9] Fernandez A., Abrahão S., \& Insfran E., "Empirical validation of a usability inspection method for model-driven Web development", Journal of Systems and Software, 86(1), 161-186, 2013.

[10] Berlilana, Hariguna T., \& Nurfaizah, "Understanding of Public Behavioral Intent to Use e-Government Service: An Extended of Unified Theory of Acceptance Use of Technology and Information System Quality", Procedia Computer Science, 124, 585-592, 2017.

[11] Belanche D., Casaló L.V., \& Guinalíu M., "Website usability, consumer satisfaction and the intention to use a website: The moderating effect of perceived risk", Journal of Retailing and Consumer Services, 19(1), 124-132, 2012.

[12] Crosby L.A., Evans K.R. \& Cowles D., "Relationship quality in services selling: an interpersonal influence perspective", Journal of Marketing, 54, 68-81, 1990.

[13] Kim E., \& Eom S., "Designing effective cyber store user interface", Industrial Management and Data Systems, 102 (5), 241-251, 2002.

[14] Maditinos D.I., \& Theodoridis K., "Satisfaction determinants in the Greek online shopping context", Information Technology and People, 23 (4), 312-329, 2010.

[15] Robins D., \& Holmes J., "Aesthetics and credibility in web site design", Information Processing and Management, 44(1), 386-399, 2008.

[16] Flavia'n C., Guinalı'u M., \& Gurrea R., "The role played by perceived usability, satisfaction and consumer trust on website loyalty", Information \& Management, 43(1), 1-14, 2006.

[17] Ayeh J.K., "Travellers' acceptance of consumer-generated media: An integrated model of technology acceptance and source credibility theories", Computers in Human Behavior, 48, 173-180, 2015.

[18] Abdeldayem M.M., "A study of customer satisfaction with online shopping: evidence from the UAE", International Journal of Advanced Media and Communication, 4(3), 235-257, 2010.

[19] Metzger M.J., \& Flanagin A.J., "Credibility and trust of information in online environments: The use of cognitive heuristics", Journal of Pragmatics, 59, 210-220, 2013.

[20] Rieh S.Y., "Judgment of information quality and cognitive authority in the web", Journal of the American Society for Information Science and Technology, 53(2), 145-161, 2002.

[21] Flanagin A.J., \& Metzger M.J., "The perceived credibility of personal Web page information as influenced by the sex of the source", Computers in Human Behavior, 19(6), 683-701, 2003.

[22] Cugelman B., Thelwall M., \& Dawes P., "Website credibility, active trust and behavioural intent", Lecture Notes in Computer Science (including Subseries Lecture Notes in Artificial Intelligence and Lecture Notes in Bioinformatics), 5033 LNCS, 47-57, 2008.

[23] Liu Z., "Perceptions of credibility of scholarly information on the Web", Information Processing and Management, 40(6), 1027-1038, 2004.

[24] Albright M.D., \& Levy P.E., "The effects of source credibility and performance rating discrepancy on reactions to multiple raters", Journal of Applied Social Psychology, 25, 577-600, 1995. 
[25] Antonio F., Pereira D.M., Saraiva A., Ramos M., Aparecida M., \& Freitas M., "Computers in Human Behavior Satisfaction and continuous useintention of e-learning service in Brazilian public organizations", Computers in Human Behavior, 46, 139-148, 2015.

[26] Fogg B.J., Soohoo C., Danielson D.R., Marable L., Stanford J., \& Tauber E.R. "How do users evaluate the credibility ofWeb sites? A study with over 2500 participants", Proceedings of the 2003 conference on designing for user experiences, (pp. 1-15). NewYork, NY, USA: ACM, 2003.

[27] Hariguna T., \& Berlilana, "Understanding of Antecedents to Achieve Customer Trust and Customer Intention to Purchase E-Commerce in Social Media, an Empirical Assessment", International Journal of Electrical and Computer Engineering, 7(3), 1240-1245, 2017.

[28] Fornell C. \& Larcker D.F., "Evaluating structural equation models with unobservable variables and measurement error", Journal of Marketing Research, 18(1), 39-50, 1981.

[29] Kaufmann L. \& Gaeckler J., "A structured review of partial least squares in supply chain management research", Journal of Purchasing and Supply Management, 21(4), 1-14, 2015.

[30] Rezaei S., "Segmenting consumer decision-making styles (CDMS) toward marketing practice: a partial least squares (PLS) path modeling approach", Journal of Retailing and Consumer Services, 22, 1-15, 2015.

\section{BIOGRAPHIES OF AUTHORS}

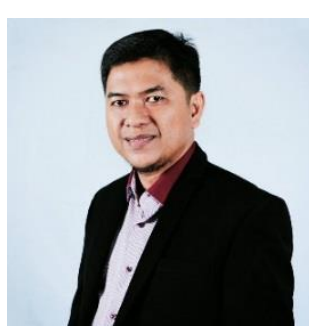

Dr. Berlilana, currently lecturer in department of information system, he also chairmen of STMIK Amikom Purwokerto. Active in some organization such as APTISI, Masyarakat Ekonomi Syariah and IEEE, he has publish some research articles in reputable publisher such as Institute of Advanced Engineering and Science (IAES), Elsevier and ACM. His research focus on Management information system, e-business and human computer behavior.

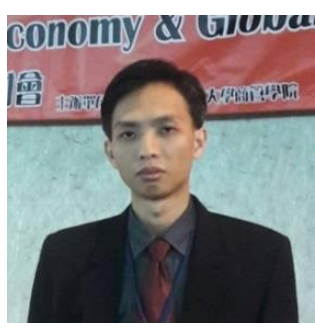

Taqwa Hariguna, Ph.D, Currently lecturer in department of information system as well as chairmen of the department at STMIK Amikom Purwokerto. Graduated from Southern Taiwan University of Science and Technology, Taiwan. He has publish some article in reputable publisher such as Institute of Advanced Engineering and Science (IAES), Elsevier, Inderscience, IEEE and ACM. His research focus on Management information system, e-business, human computer behavior, IT/IS Strategic and IT/IS for government.

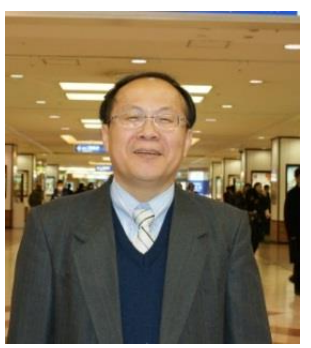

Prof. Dr. Min Tsai Lai, Currently Vice President of Southern Taiwan University of Science and Technology, Taiwan. He has publish some article in reputable publisher such as Elsevier, Emerald, Springer, Taylor \& Francis and Inderscience. His research focus on Statistic, Management Science and Industrial Management. 